\title{
Resisting punching shear stress in reinforced concrete slabs
}

\author{
Ebada Ahmed ${ }^{1}$, Boshra Eltaly $^{1}$, Fatma El-Zhraa $^{1}$ and Magdy Tayel $^{1}$ \\ ${ }^{1}$ Faculty of Engineering, Minoufia University, Minoufia, Egypt
}

\begin{abstract}
Punching shear failure is a major problem encountered in the design of reinforced concrete flat slabs. The utilization of shear reinforcement via shear studs or other means has become a choice for improving the punching shear capacity. In this study, a new alternative of reinforcement modalities were tested and demonstrated the effect of self-compact concrete on the punching shear capacity, beside that compared between the difference codes to identify the suitable one for determining the position of critical section of punching shear. Nevertheless, in this investigation, the proposed reinforcement system is examined for interior columns only. An experimental work consisting of six specimens: five of them were cast with normal reinforced concrete and one was cast with self-compact strength concrete. The obtained results indicate that the proposed shear reinforcement system has a positive effect in the enhancement of the punching shear capacity of interior slab-column connection of self-compact strength concrete.
\end{abstract}

\section{Introduction}

Punching shear is a critical design factor of reinforced concrete flat slabs since it is associated with brittle failure. The punching shear strength and deformation capacity are strongly influenced by the type and characteristics of the shear reinforcing system. Ruiz and Muttoni [1] carried out a series of a six full scale slab tests $(3.0 \times 3.0 \times 0.25 \mathrm{~m})$ with the same flexural and shear reinforcing ratio. The slabs were different punching shear reinforcing systems; e.g., separated stirrups, continuous stirrups, bonded reinforcement with anchorage plates, vertical studs and inclined studs. The improvement in punching shear strength and ductility as a result of these systems increased with the same order as they have been mentioned, with the vertical and inclined studs giving the best results; $77 \%$ and $119 \%$ improvement, respectively. Bent-up bars also improve the punching shear strength and deformation capacity as reported by Tassinari [2]. Lips [3] and Lips and Muttoni [4] demonstrated the positive effect of both shear studs and continuous stirrups on the punching shear strength and deformation capacity of slab-column connection. The same conclusion was achieved by Pilakoutas [5] for inclined shear band reinforcement. The shear strength is proportional to the flexural reinforcement ratio; in contrast, the rotation capacity is inversely proportional to the flexural reinforcement [6]. This study explored the possibility of enhancing the punching shear strength by introducing horizontal mesh reinforcement at the middle of the depth of slab-column connection zone. This reinforcement arrangement is easy to apply and economic in comparison with the other reinforcement types. Kueres et al[7], evaluated the punching shear design provisions according to Eurocode 2 by means of comparisons with test results. To verify the changes in the current design provisions, the new design method was evaluated using large databanks for flat slabs and column bases without and with shear reinforcement as well as systematic test series. The evaluation of the large databanks indicates a well-balanced level of safety of the proposed design method for all investigated types of members. Mabrouk et al., [8] asses the contribution of horizontal flexural reinforcement and vertical shear reinforcement on the punching behavior of reinforced concrete flat slabs. The result from this study showed that the failure of all the tested specimens was a brittle punching failure, adding vertical shear reinforcement in the form of stirrups improved the punching capacity of the slabs, increasing the width of stirrups caused a slight increase in the punching strength, also as the flexural reinforcement ratio was increased, the punching capacity was increased. Finally the current Egyptian code is more conservative than the ACI code in estimating the punching shear capacity.

Self-compacting concrete (SCC) is one of the new types of concrete that possesses High flow-ability, passing ability and stability. It is a highly workable concrete that can flow through congested reinforcing under its own weight and sufficiently fill voids without tending to segregation or excessive bleeding and without the need for Vibration to consolidate it [9-11]. In addition, selfcompacting concrete should maintain its flow-ability for a reasonably long time [12].

The provisions for calculating the ultimate punching shear capacity recommended by different building codes are reviewed in the following: 
- In the Egyptian Code of Practice, ECP-203 [13], the critical shear perimeter is located at a distance $0.5 \mathrm{~d}$ from the column face, it does not account for the flexural reinforcement effect and the concrete strength is limited to $40 \mathrm{MPa}$. Besides, it does not take into consideration the contribution of punching shear reinforcement.

- According to the ACI 318-11 [14], the critical perimeter is assumed at $0.5 \mathrm{~d}$ from the perimeter of the loaded area.

- The critical section adopted by the British Standard, BS-8110 [15], lies at $1.5 \mathrm{~d}$ from the column face. If shear reinforcement is considered, then it should be provided on at least two perimeters within the punching zone. The first perimeter of reinforcement should be located at approximately $0.5 \mathrm{~d}$ from the face of the loaded area and should contain not less than $40 \%$ of the calculated area of reinforcement. The spacing of perimeters of reinforcement should not exceed $0.75 \mathrm{~d}$ and the spacing of the shear reinforcement around any perimeter should not exceed $1.5 \mathrm{~d}$. The shear reinforcement should be anchored round at least one layer of tension reinforcement. The shear stress should then be checked on successive perimeters at $0.75 \mathrm{~d}$ intervals until a perimeter is reached which does not require shear reinforcement.

- The critical section adopted by the Eurocode 2, EC2 [16], lies at $2 \mathrm{~d}$ from the column face, In case of shear reinforcement, a control perimeter set at a distance of $1.5 \mathrm{~d}$ from the outer most perimeter of shear reinforcement

The main objective of the current work is to compare the punching shear strength of six flat slabs; one made from self-compact concrete, and the remaining made with normal strength concrete, four of these normal slabs were strengthened by bent bar at different location from the column face and one without strengthened to be used as a control slab.

\section{Experimental work}

\subsection{Test specimens}

An experimental program were consisting of six square flat slab specimens. One specimen was cast with selfcompact concrete and the others specimens were cast with normal strength concrete (the control specimen and four specimens strengthened against the shear punching). The specimens ABBS1, ABBS2 and ABBS3 were strengthened by bent bar started at $0.5 \mathrm{~d}, 1.0 \mathrm{~d}$ and $1.5 \mathrm{~d}$, respectively from the column face in two directions, the remaining specimen ABBS4 was strengthened by bent bar in which the middle of it was at $0.5 \mathrm{~d}$ from the column face. Where $d$ is the distance between the column face and bent bar. The details of test specimens are indicated in Table 1 and in Figs. 1\&2. All the test specimen consisted of square flat slabs $1200 \mathrm{~mm}$ length and $140 \mathrm{~mm}$ thick with $200 \mathrm{~mm}$ square reinforced concrete column stubs extending $200 \mathrm{~mm}$ above the slabs. The column stub was cast monolithically with the slab. All the slabs were identical in dimensions. The reinforcement was distributed uniformly throughout the width of the slab as shown in Figs. 1 and 2.

\subsection{Properties of materials}

Natural siliceous sand was used as the fine aggregate throughout the current research. The sieve analysis was done on the sand and its result is presented in Table 2. Natural dolomite from Suez zone was used as a coarse aggregate. The dolomite has a nominal maximum size of $(20 \mathrm{~mm})$. The particles were smooth in texture with 80 percent of them angular shape. The sieve analysis for the dolomite used is shown in Table 3. Ordinary Portland cement was used and its chemical and physical properties were analyzed according to E.S.S. (2011) for concrete works. Fresh drinking water and free from impurities was used for mixing and curing of the test specimens.

For the concrete strength; standard cubes have been tested for strength control. Table 4 shows the average strength of all specimens designated as $25 \mathrm{MPa}$ for normal slab concrete and $40 \mathrm{MPa}$ for self-compact concrete slab. Based on the results of different trail mixes, the concrete mix proportions illustrated in Table 5 were selected to cast the test specimens with normal strength concrete. The concrete mix proportions illustrated in Table 6 were selected to cast the test specimen with self-compact concrete.

High tensile steel bars with $10 \mathrm{~mm}$ diameters were used as main and secondary reinforcement in the two directions of tested slabs. The concrete columns were reinforced with normal mild steel as stirrups with $8 \mathrm{~mm}$ diameters and high tensile steel bars with $10 \mathrm{~mm}$ diameters as main reinforcement. Table 7 illustrates mechanical properties of steel reinforcement.

\subsection{Preparation of test specimens}

Six square wooden forms for slab specimens $120 \times 120 \times 14 \mathrm{~cm}$ with stub columns $20 \times 20 \times 20 \mathrm{~cm}$ at the center of each slab specimen were prepared. The reinforcement was then placed in their right position in the forms (Fig. 3). Wooden forms for the stub columns were installed at the center of the specimens. A 50 liter capacity mixer was used with a speed of about 50 revolutions per minute. Materials were added in the following sequence: coarse aggregate, sand and cement. The dry constituents were mixed without water for two minutes, then the water was added and the operation continued for an additional three minutes to ensure adequate mixing as shown in Fig. 4. The forms were coated with oil before casting. The concrete mix was charged out from the mixer bowl. A mechanical vibrator was used in placing the concrete around the reinforcing bars together with the hand tamping and rodding to ensure full compaction. The slabs specimens were left in the forms for 24 hours after which the sides of the forms were stripped. The specimens were cured by water sprinkling twice a day for 28 days. 


\subsection{Test set-up}

The specimens were tested in Al-Menoufia University Reinforced Concrete Lab. The models were tested under concentrated loads at the center of the column stub up to failure. Loads were applied in increments using a hydraulic jack of 100 ton maximum capacity. Dial gauges of $0.01 \mathrm{~mm}$ accuracy and total capacity of $25 \mathrm{~mm}$ were used for measuring deflections, first cracking loads and ultimate failure loads were recorded. Propagation of cracks was marked after each load increment up to failure. The description of loading system is shown in Fig. 5, while Fig .6 shows the arrangements of the dial gauges for different specimens.

\section{Results and discussion}

The behavior of the test specimens in terms of loaddeflection relationship and mode of failure are illustrated and discussed in the current sections. Load-deflection curves for all specimens are presented in Fig. 7. Table 8 shows the experimental results of all the tested slabs in the terms of ultimate and first crack load, the deflection at the failure and at the first crack load, ductility ratio and energy absorption. The ductility ratio was calculated as ratio of the mid span deflection at the ultimate load to that at the first cracking load. The energy absorption was obtained by calculating the area under the loaddeflection curve for each slab. Fig. 8 shows the ultimate and the first crack loads for all tested slabs. The average ductility ratio and energy absorption for all tested slabs are shown in Fig. 9.

\subsection{Effect of concrete strengthening}

Fig. 10 shows the comparison between load-deflection curves at the center (D1) of the control slab S025 and specimen S040, and at the midpoint (D3) between the center of slab and the support. The ultimate load and the first crack load for self-compact concrete (S040) was higher than the control slab (S025) by $30 \%$ and $25 \%$, respectively.

\subsection{Effect of bent bars position}

Fig. 11 illustrates comparison between load-deflection curves at D1 and D3 for control slab (S025) and Group $\mathrm{C}$ (ABBS1, ABBS2 and ABBS3). The results shows that the ABBS1 has the highest ultimate load and it was double load of the control slab, the ABBS2 was higher than the control slab by about $70 \%$ for ultimate load and by about $50 \%$ for first crack load, the lowest load for experimental groups was associated with ABBS3, it was $60 \%$ and $20 \%$ higher than the control slab for ultimate load and the first crack load, respectively.

\subsection{Effect of start and middle of bent bar at $0.5 \mathrm{~d}$}

Comparison between load-deflection curves at D1 and D3 for the specimen ABBS1 and ABBS4 in which the specimens was strengthened at $0.5 \mathrm{~d}$ by bent bar at start and at the middle from the column face in two directions; respectively was shown in Fig. 12. The results show that ABBS4 has higher ultimate and first crack loads $(375 \mathrm{KN}$ and $175 \mathrm{KN})$ than control group $(250 \mathrm{kN}$ and $100 \mathrm{kN})$, but it is lower than that for ABBS1 (500 kN and $200 \mathrm{kN})$.

\subsection{Crack observations}

For all the specimens, surface cracks on the tension side of reinforcement, had been observed and marked during the test. The initial crack development in all specimens followed a similar pattern. Diagonal cracks were getting wider and tangential cracks had been developed. Fig. 13 shows the crack pattern in the tension side for all specimens. For the compression side, cracks had been developed around the column in all specimens.

\section{Conclusions}

The main goal of the current research is examining the punching shear resistance of flat slab by using selfcompact concrete and using additional modalities of bent bar reinforcement, to compare between different codes in order of identifying the suitable code for determining the position of critical section of punching shear. From the experimental results, the following conclusions could be drawn as below:

1-The increase of strength concrete lead to increase of ultimate load of slab, and this explain the high resistance of punching shear strength of self-compact concrete.

2-The critical parameter of punching shear lay at 0.5 $\mathrm{d}$ from the column face, so the Egyptian code is the best international code for determining the critical section of punching shear.

3-Strengthening of slab at position more or less than $0.5 \mathrm{~d}$ leads to reduce of punishing shear resistance of slab.

\section{References}

1. Ruiz F. M. and Muttoni A. "Performance and design of punching shear reinforcing systems", 3rd Fib International Congress, 2010.

2. Tassinari L., Lips S., Muttoni A., and Ruiz MF, "Applications of bent-up bars as shear and integrity reinforcement in R/C slabs", Session 2B-5: construction Technology, 2011.

3. Lips S., "Punching of flat slabs with large amounts of shear reinforcement", Ecole Polytechnique Federale de Lausanne, 2012.

4. Lips S., and Muttoni A., "Experimental investigation of reinforced concrete slabs with punching shear reinforcement", 8th Fib PhD Symposium, Lyngby, Denmark, 2010.

5. Pilakoutas K., and Li X. "Alternative shear reinforcement for reinforced concrete flat slabs", Journal of Structural Engineering, Vol. 129, No. 9pp.1164-72, 2003.

6. Kinnunen S., and Nylander H., "Punching of concrete slabs without shear reinforcement", Transactions of the 
Royal Institute of Technology, No. 158, Stockholm, Sweden, pp. 112, 1960.

7. Kueres D., Siburg C., Herbrand M., Classen M., and Hegger J. "Uniform Design Method for punching shear in flat slabs and column bases", Engineering Structural, Vol. 136,149-64, 2017.

8. Mabrouk R. T. S., Bakr A., and Abdalla H. "Effect of flexural and shear reinforcement on the punching behavior of reinforced concrete flat slabs", Alexandria Engineering Journal, 2017.

9. Okamura H., and Ouchi M. "Self-compacting concrete, development, present use and future", Proceeding of the 1st international RILEM symposium on self- compacting concrete, stochkolm, RILEM Publications, 1999.

10. Yahia A., Tanimura M., Shimabukuro A., and Shimoyama Y. "Effect of rheological parameters on self compactibility of concrete containing various mineral admixtures" Proceedings of the 1 st international RILEM symposium on self-compacting concrete, Stockholm, RILEM Publications, 1999.

11. Ozawa K., Sakata N., and Okamura H., "Evaluation of self-compact ability of fresh concrete using the funnel test", Concrete Library JSCE, 1995.

12. Okamura H., and Ozawa K. "Mix design for selfcompacting concrete", Concrete Library JSCE, 1995.

13. Egyptian Code Committee 203, Egyptian Code of Practice for Design and Construction of Reinforced Concrete Structures, Housing and Building Research Centre, Cairo, 2007 (in Arabic).

14. American Concrete Institute, ACI-318, Building Code Requirements for Structural Concrete, ACI 318-11, ACI Committee 318, pp. 503, Detroit, USA, 2011.

15. British Standards Institution, Structural Use of Concrete, BS- 8110: Part 1-Code of Practice for Design and Construction, London, 1997.

16. Eurocode 2, Design of Concrete Structures, Part 1-6, General Rules and Rules for Buildings, European Prestandard, European Committee for Standardization, 1992. 
Table 1. Details of the test specimens

\begin{tabular}{|c|c|c|c|c|c|c|}
\hline Group & $\begin{array}{c}\text { Specimen } \\
\text { Code }\end{array}$ & $\begin{array}{c}\text { Fcu } \\
\mathbf{( M P a}\end{array}$ & Conditions & $\begin{array}{c}\text { Bottom } \\
\text { RFT }\end{array}$ & Top RFT & Bent Bar \\
\hline (A) & S025 & 25 & Control & $6 \varnothing 10$ & $8 \varnothing 10$ & - \\
\hline (B) & S040 & 40 & Self-compact concrete & $6 \varnothing 10$ & $8 \varnothing 10$ & - \\
\hline & ABBS1 & 25 & $\begin{array}{c}\text { Strengthen by bent bar } \\
\text { started at } 0.5 \text { d from the } \\
\text { column face }\end{array}$ & $6 \varnothing 10$ & $8 \varnothing 10$ & $4 \varnothing 10$ \\
\cline { 2 - 7 } (C) & ABBS2 & 25 & $\begin{array}{c}\text { Strengthen by bent bar } \\
\text { started at } 1.0 \text { d from the } \\
\text { column face }\end{array}$ & $6 \varnothing 10$ & $8 \varnothing 10$ & $4 \varnothing 10$ \\
\cline { 2 - 7 } & ABBS3 & 25 & $\begin{array}{c}\text { Strengthen by bent bar } \\
\text { started at } 1.5 \text { d from the } \\
\text { column face }\end{array}$ & $6 \varnothing 10$ & $8 \varnothing 10$ & $4 \varnothing 10$ \\
\hline (D) & ABBS4 & 25 & $\begin{array}{c}\text { strengthen by bent bar in } \\
\text { which the middle of it was } \\
\text { at } 0.5 \text { d from the column } \\
\text { face }\end{array}$ & $6 \varnothing 10$ & $8 \varnothing 10$ & $4 \varnothing 10$ \\
\hline
\end{tabular}

Table 2. Grading of fine aggregate according to (ASTM C33).

\begin{tabular}{|c|c|c|c|c|c|c|c|}
\hline Sieve size (mm) & $\mathbf{9 . 5}$ & $\mathbf{4 . 7 5}$ & $\mathbf{2 . 3 6}$ & $\mathbf{1 . 1 8}$ & $\mathbf{0 . 6 1}$ & $\mathbf{0 . 3 1}$ & $\mathbf{0 . 1 6}$ \\
\hline \% passing (ASTM C33) & 100 & $95-100$ & $80-100$ & $50-85$ & $25-60$ & $5-30$ & $0-10$ \\
\hline \% passing used dolomite & 100 & 100 & 96 & 75 & 45 & 20 & 1 \\
\hline
\end{tabular}

Table 3. Grading of Coarse Aggregate According to (ASTM C33) and Grading of Natural Dolomite Used.

\begin{tabular}{|c|c|c|c|c|c|}
\hline Sieve size (mm) & $\mathbf{2 0}$ & $\mathbf{1 2 . 5}$ & $\mathbf{9 . 5}$ & $\mathbf{4 . 7 5}$ & $\mathbf{2 . 3 6}$ \\
\hline \% passing (ASTMC33) & 100 & $90-100$ & $40-70$ & $0-15$ & $0-5$ \\
\hline \% passing used dolomite & 100 & 96 & 85 & 53.2 & 7.3 \\
\hline
\end{tabular}

Table 4. Used material properties

\begin{tabular}{|c|c|c|}
\hline Cubes number & F cu (MPa) & Average (MPa) \\
\hline 1 & 27.32 & \multirow{4}{*}{$\begin{array}{l}\text { Normal strength concrete } \\
25\end{array}$} \\
\hline 2 & 26.89 & \\
\hline 3 & 26.49 & \\
\hline 4 & 24.65 & \\
\hline 5 & 39.81 & \multirow{3}{*}{$\begin{array}{c}\text { Self-compact concrete } \\
40\end{array}$} \\
\hline 6 & 43.65 & \\
\hline 7 & 42.21 & \\
\hline
\end{tabular}

Table 5. Concrete mix design (normal strength concrete $25 \mathrm{MPa}$ )

\begin{tabular}{|c|c|c|c|}
\hline Cement & Water & Coarse aggregate & Fine aggregate \\
\hline $300 \mathrm{~kg}$ & $150 \mathrm{~kg}$ & $1290 \mathrm{~kg}$ & $645 \mathrm{~kg}$ \\
\hline
\end{tabular}

Table 6. Concrete mix design (self-compact concrete $40 \mathrm{MPa}$ )

\begin{tabular}{|c|c|c|c|c|c|}
\hline Cement & Water & $\begin{array}{c}\text { Coarse } \\
\text { aggregate }\end{array}$ & Fine aggregate & Flyash & ViscoCrete \\
\hline $425 \mathrm{~kg}$ & $148 \mathrm{~kg}$ & $838 \mathrm{~kg}$ & $686 \mathrm{~kg}$ & $85 \mathrm{~kg}$ & $17 \mathrm{~kg}$ \\
\hline
\end{tabular}

Table 7. Mechanical properties of steel reinforcement

\begin{tabular}{|c|c|c|c|c|}
\hline Steel Type & $\begin{array}{c}\text { Yield Stress } \\
\text { (kg/cm2) }\end{array}$ & $\begin{array}{c}\text { Tensile Strength } \\
(\mathbf{k g} / \mathbf{c m} 2)\end{array}$ & $\begin{array}{c}\text { Elongation } \\
\mathbf{\%}\end{array}$ & $\begin{array}{c}\text { Modulus of } \\
\text { Elasticity (t/cm2) }\end{array}$ \\
\hline High Tensile & 3675 & 5350 & 16.0 & 2100 \\
\hline Normal Mild & 2550 & 3750 & 24.30 & 2050 \\
\hline
\end{tabular}


Table 8. Experimental results

\begin{tabular}{|c|c|c|c|c|c|c|}
\hline \multirow{2}{*}{$\frac{\text { 흔 }}{\omega}$} & \multicolumn{2}{|c|}{ Load (KN) } & $\begin{array}{c}\text { Deflection at } \\
\text { Ultimate Load } \\
\text { (mm) }\end{array}$ & $\begin{array}{c}\text { Deflection at } \\
\text { First Crack } \\
\text { (mm) }\end{array}$ & $\begin{array}{c}\text { Ductility } \\
\text { Ratio }\end{array}$ & $\begin{array}{c}\text { Energy } \\
\text { Absorption } \\
\text { (KN.mm) }\end{array}$ \\
\hline S025 & 250 & 100 & 6.50 & 2.6 & 2.50 & 78.12 \\
\hline S040 & 325 & 125 & 8.20 & 2.15 & 3.81 & 1528.00 \\
\hline ABBS1 & 500 & 200 & 9.0 & 2.04 & 4.41 & 3027.50 \\
\hline ABBS2 & 425 & 150 & 8.10 & 1.49 & 5.44 & 2209.50 \\
\hline ABBS3 & 400 & 120 & 7.60 & 1.12 & 6.79 & 1917.40 \\
\hline ABBS4 & 375 & 175 & 8.40 & 3.42 & 2.46 & 1721.50 \\
\hline
\end{tabular}

A)

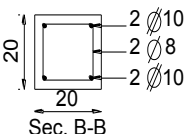

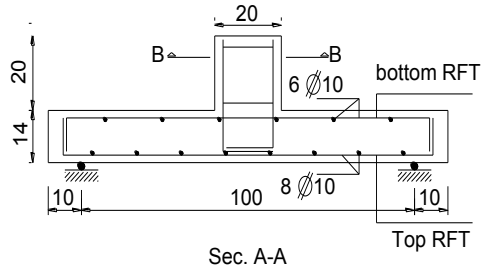

B)
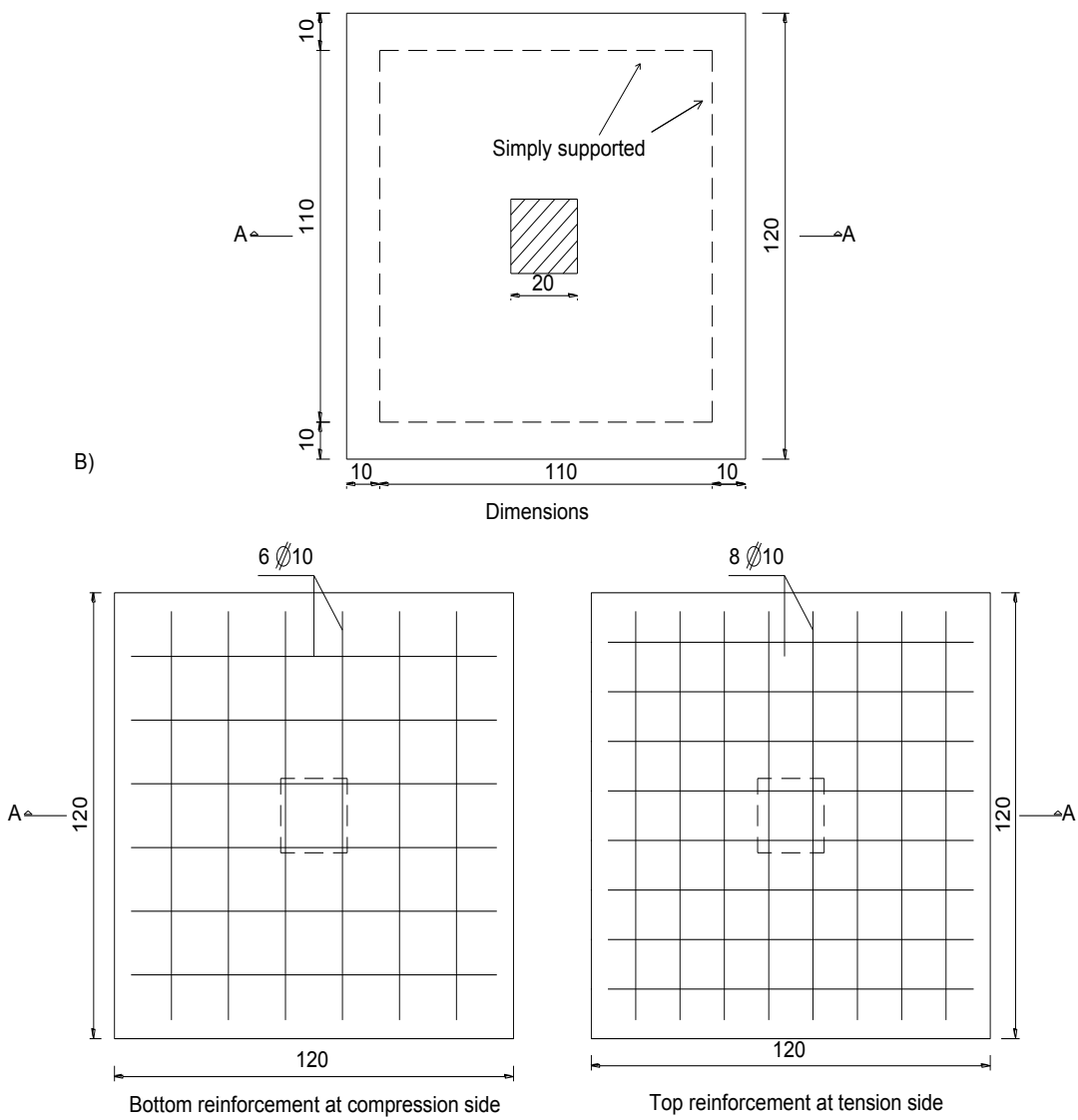

Top reinforcement at tension side

Fig. 1. A) Dimensions of slabs, B) Details of reinforcement of reference S025, S040, Dimensions in cm. 


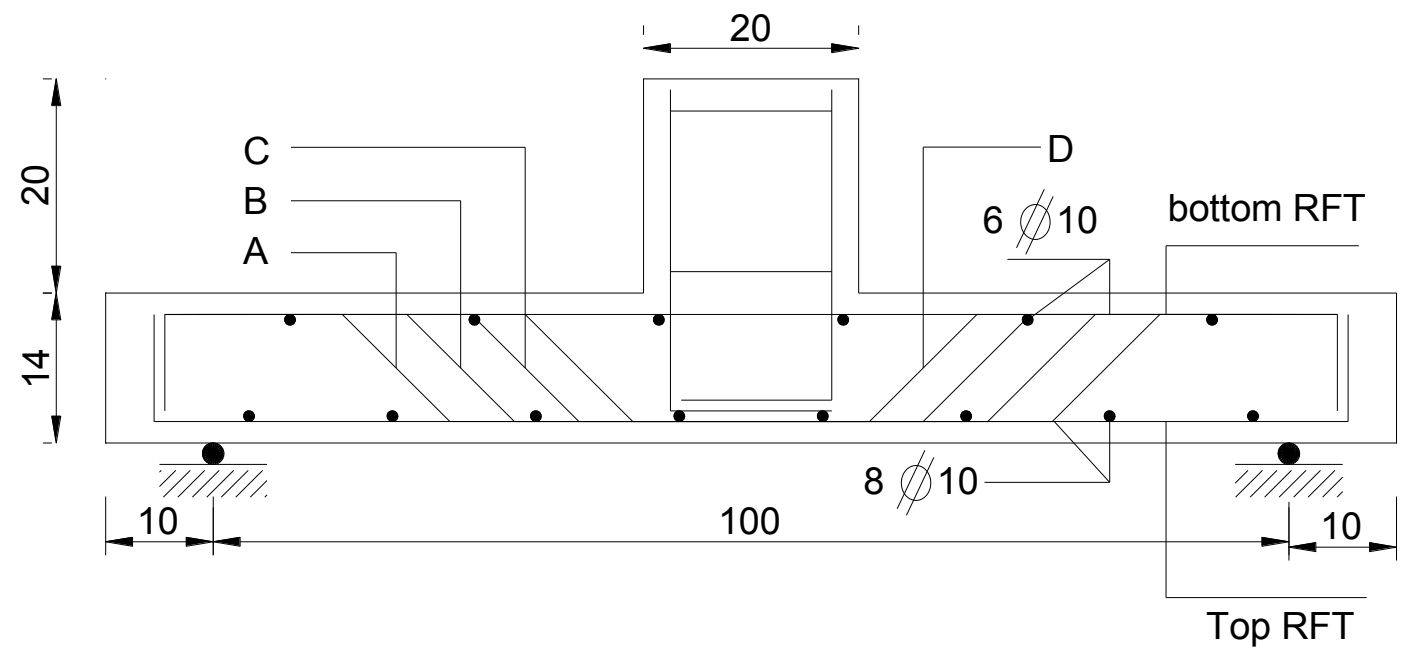

Fig. 2. Typical steel arrangement details of slabs: A) Start of bent bar at $1.5 \mathrm{~d}$ from column face, B) Start of bent bar at $1.0 \mathrm{~d}$ from column face, C) Start of bent bar at $0.5 \mathrm{~d}$ from column face, D) Middle of bent bar at $0.5 \mathrm{~d}$ from column face, Dimensions in $\mathrm{cm}$.

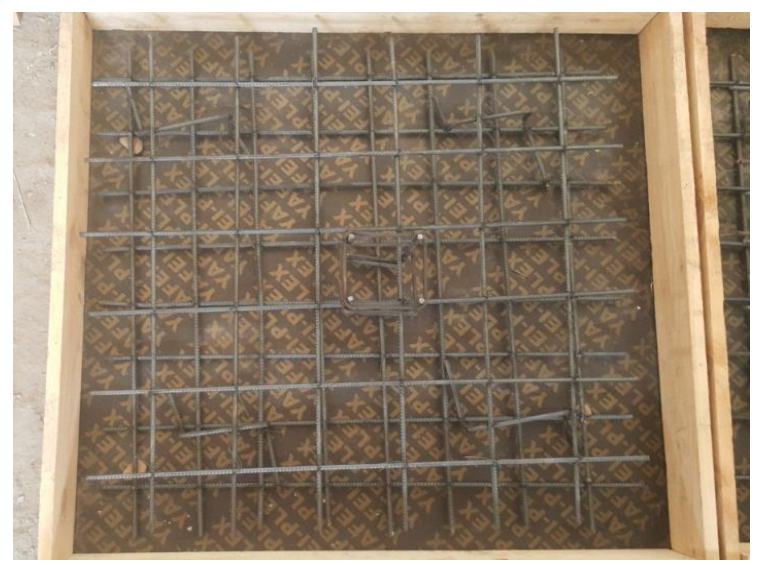

Fig. 3. Wooden forms and reinforcement.

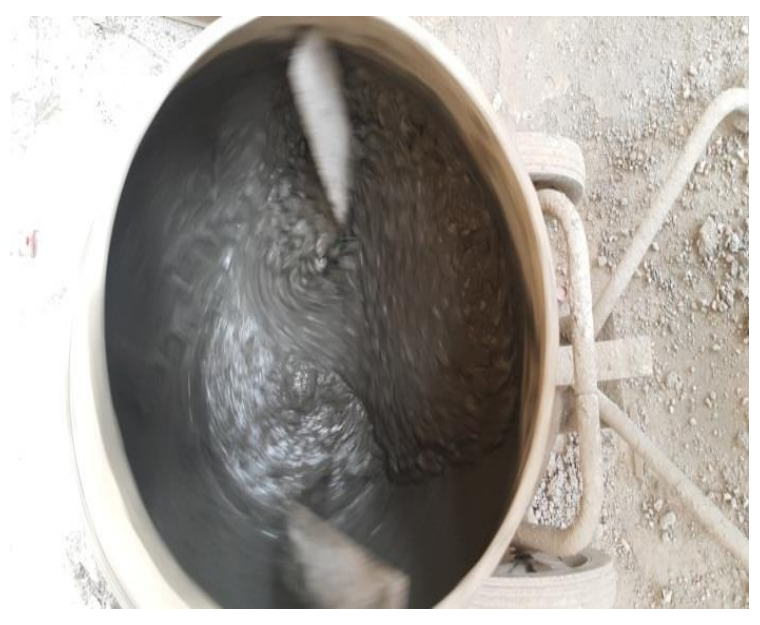


Fig. 4. Mixing of materials

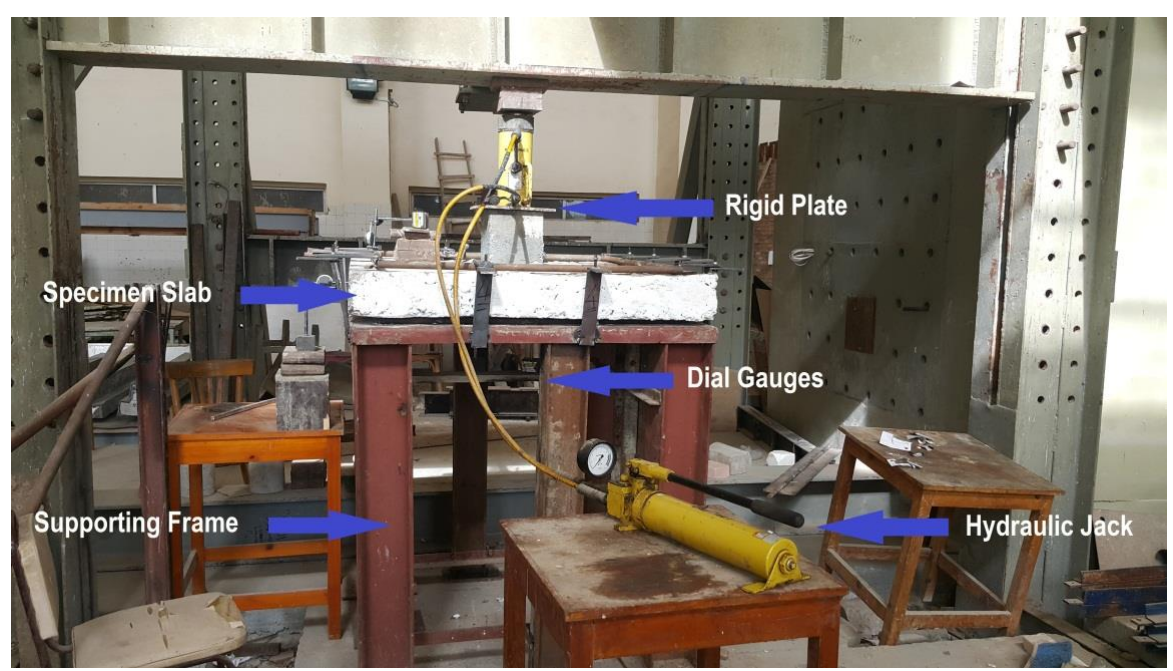

Fig. 5. Description of the loading system.

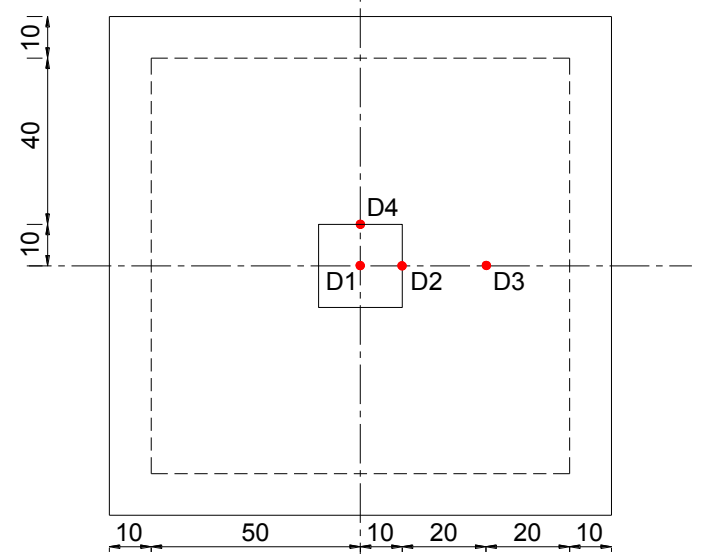

Fig. 6. Arrangements of dial gauges for different specimens, Dimensions in $\mathrm{cm}$

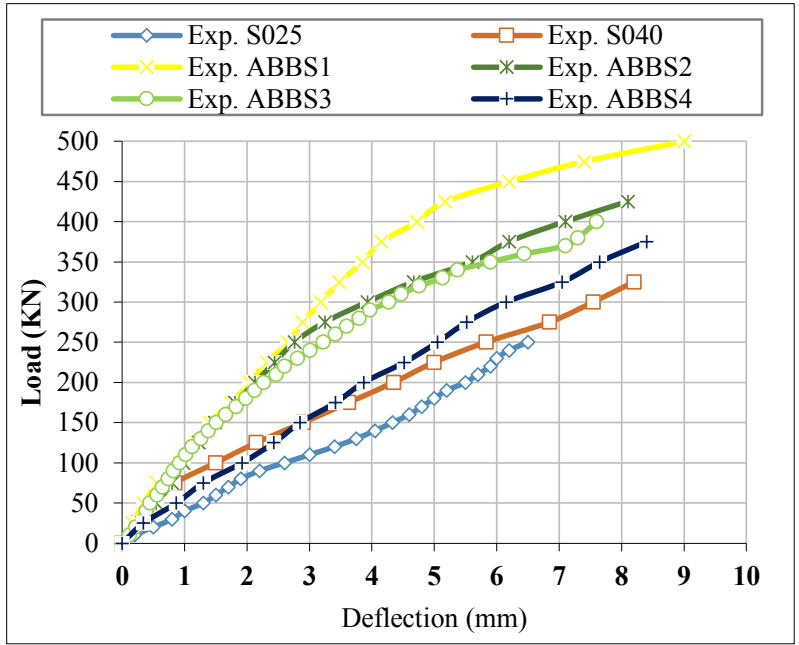


Fig.7. Load-deflection curves of all test specimens at D1

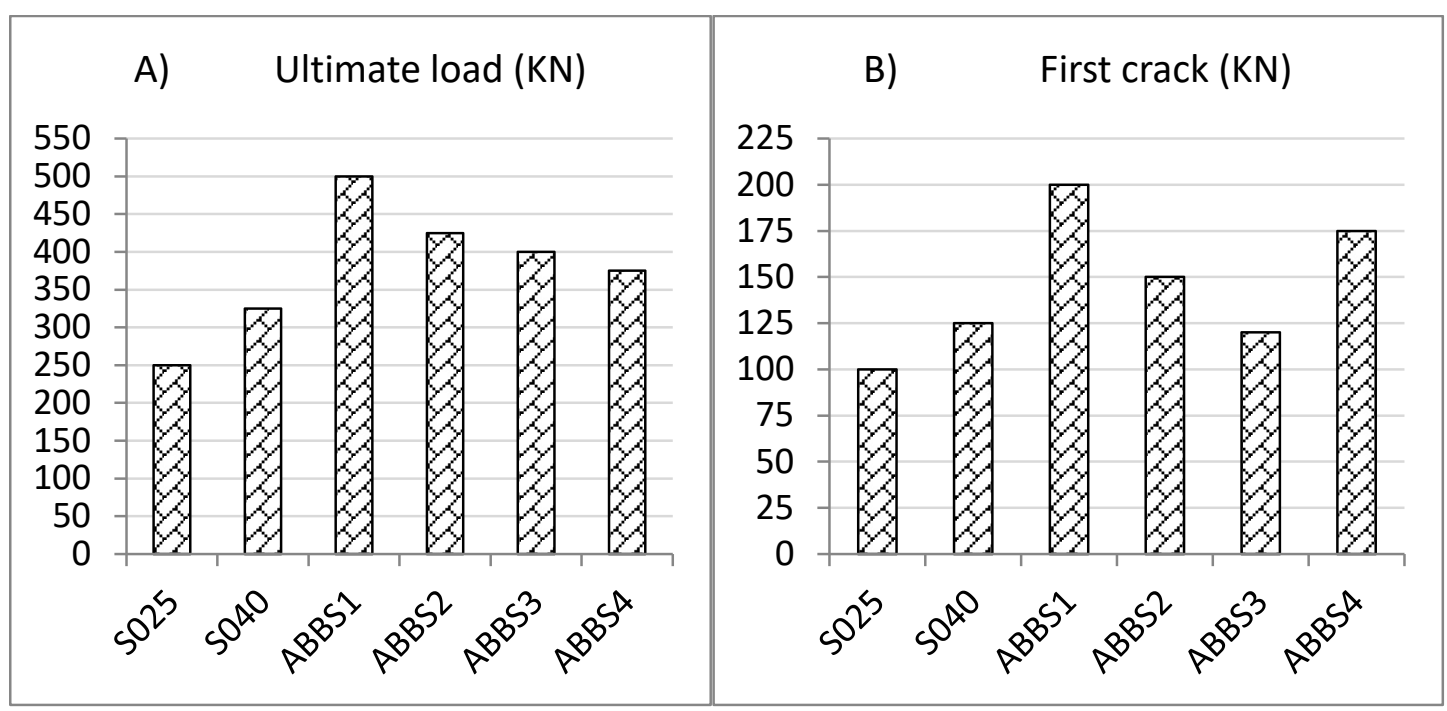

Fig. 8. A) Ultimate load for all tested slabs, B) First crack load for all tested slabs

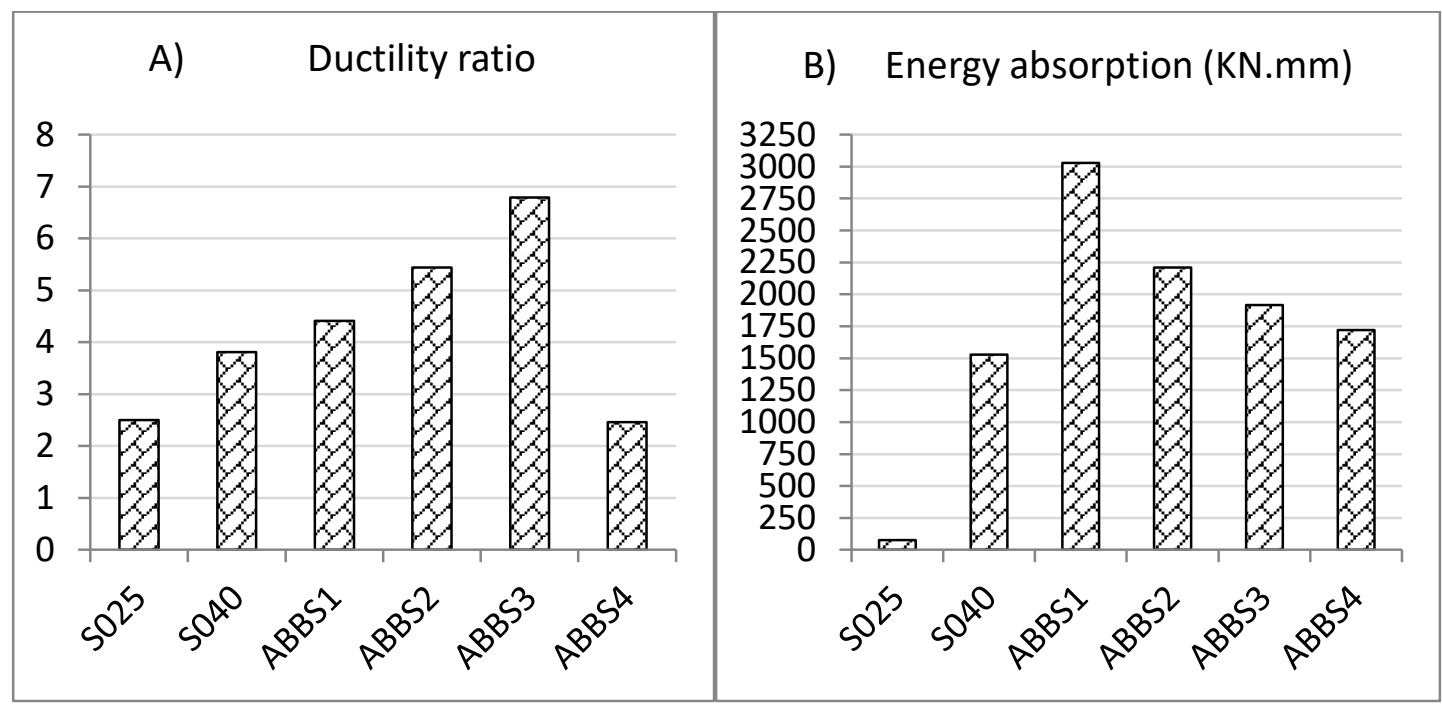

Fig. 9. A) The average ductility ratio for all tested slabs, B) Energy absorption for all tested slabs

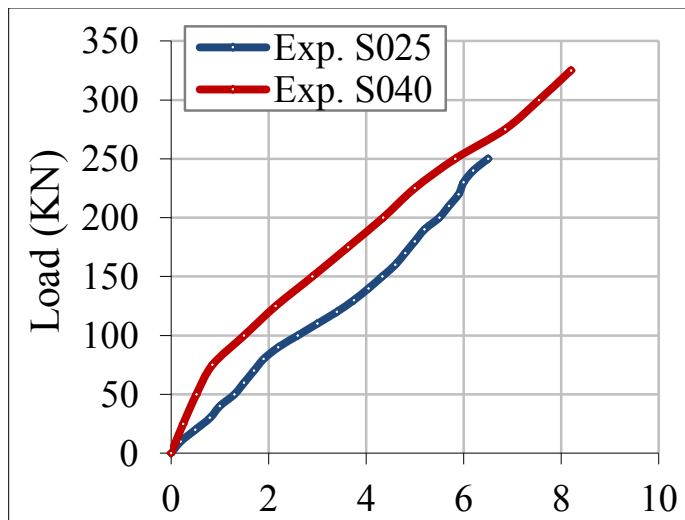

A)

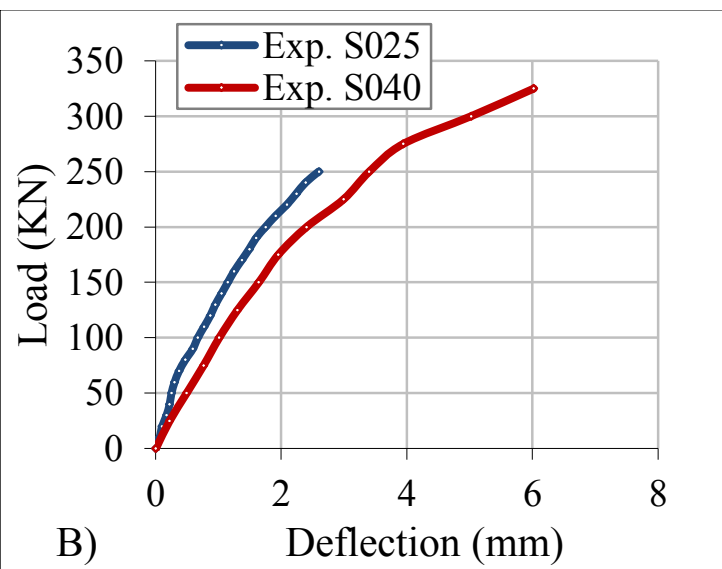


Fig. 10. Comparison between load-deflection curves of the specimens S025 and S040, A) load-deflection at D1, B) loaddeflection at D3.

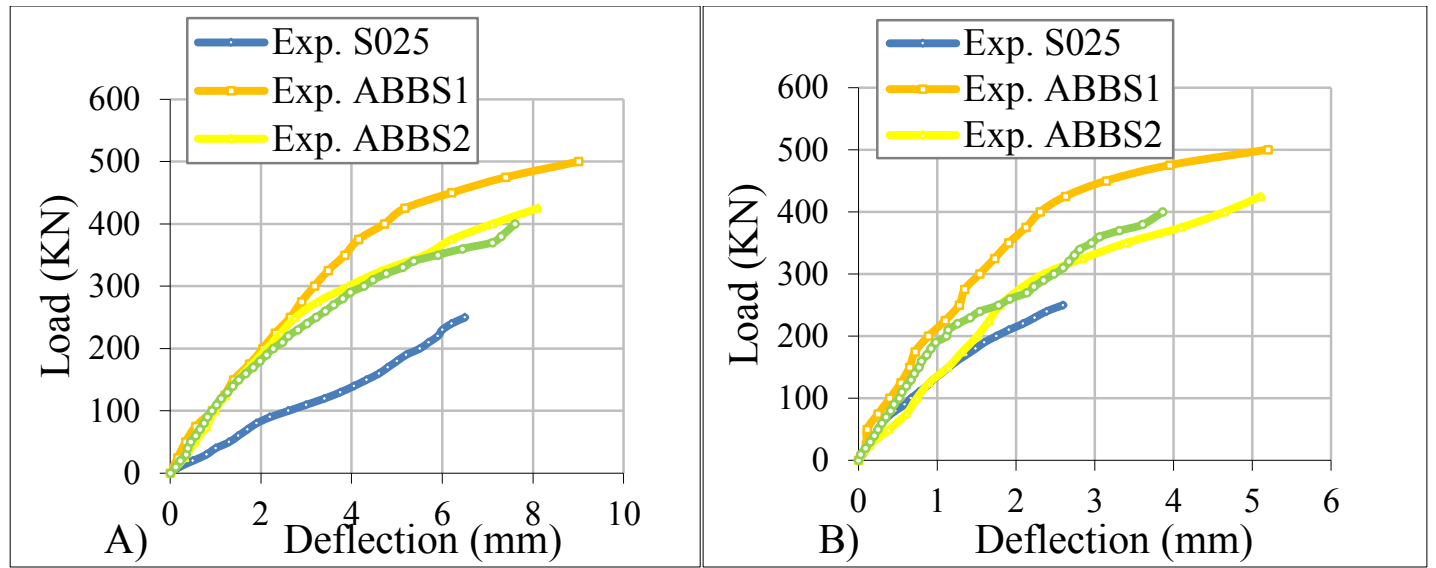

Fig. 11. Comparison between load-deflection curves of the specimens S025 and all specimens of Group D: A) load-deflection at D1 and B) load-deflection at D3.

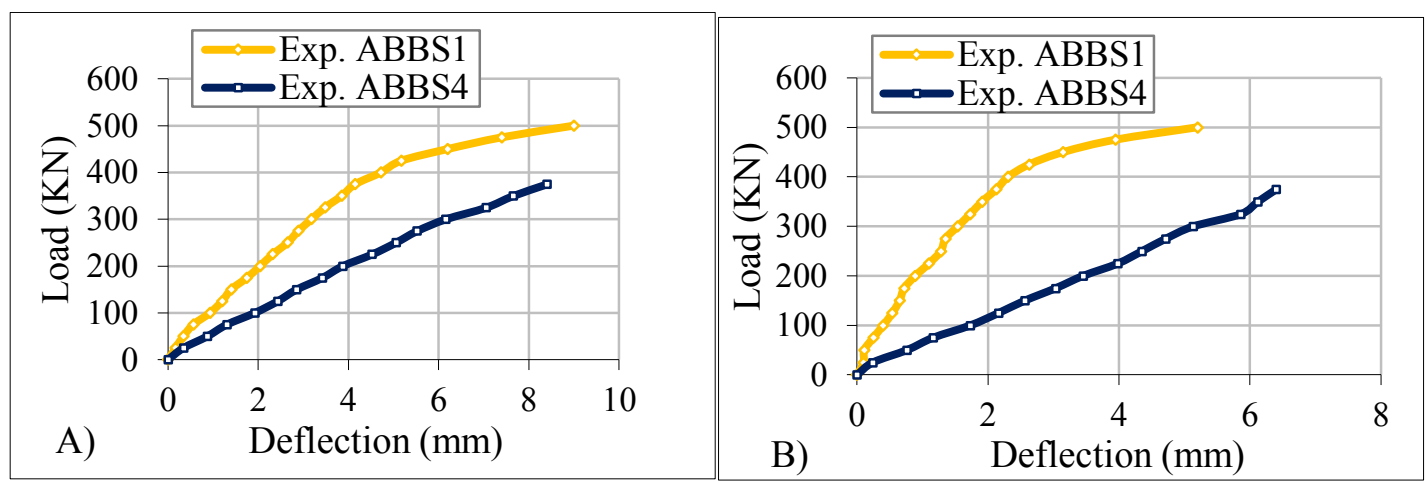

Fig. 12. Comparison between load-deflection curves of the specimens ABBS1 and ABBS4; A) load-deflection at D1, B) load-deflection at D3. 

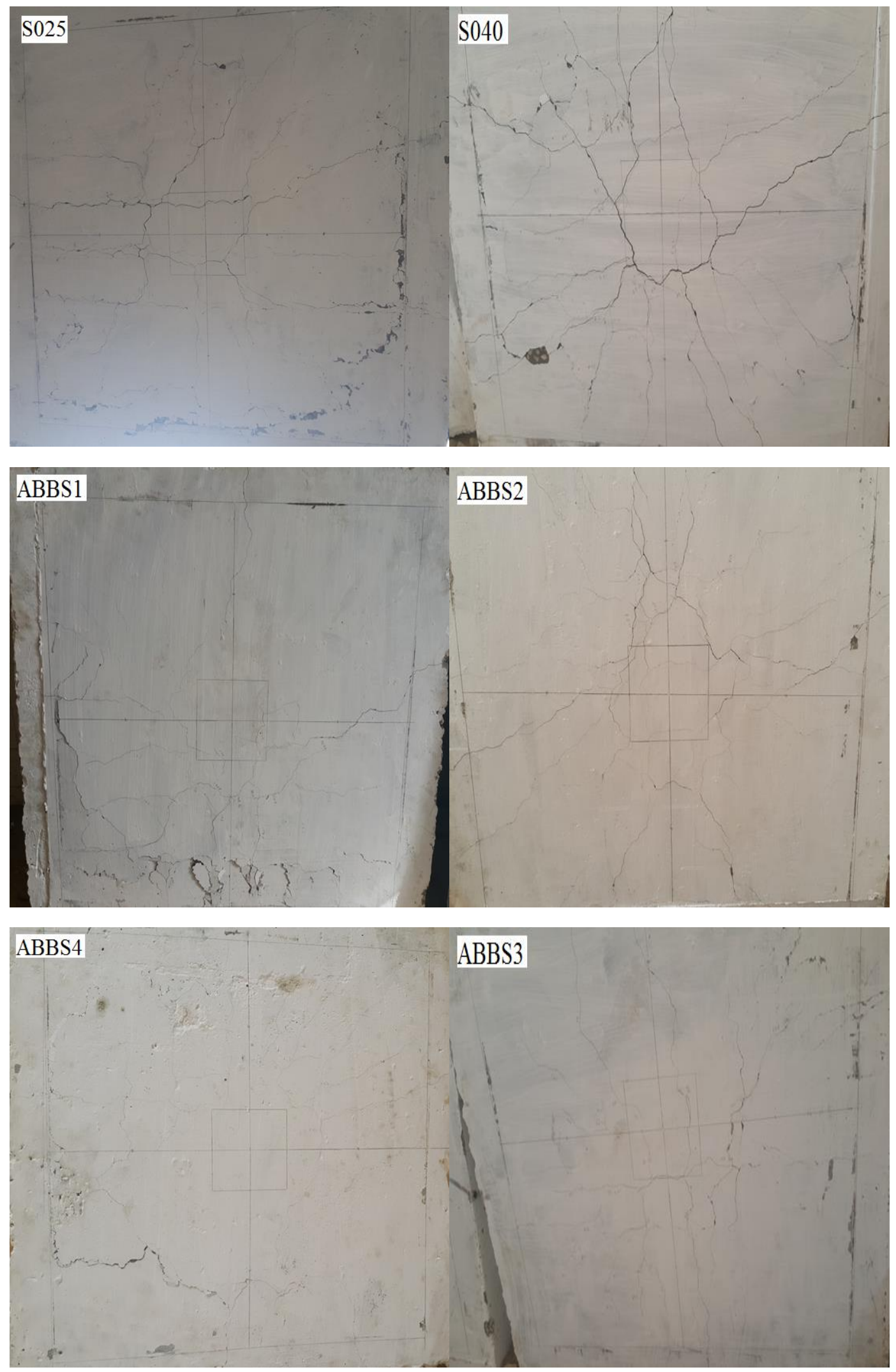

Fig. 13. The crack pattern (propagation) in tension side for all specimens 